\title{
Appendix: The Catholic Bishops and Dr. Eugen Kogon
}

August 23, $1947^{1}$

Subject: The Catholic bishops and Dr. Kogon

To: Office of Military Government for Greater Hesse Information Control Division, APO 633. Us Army (attn.: Chief Research Branch)

From: Richard G. Akselrad, Fulda Detachment

In the July issue of the Frankfurter Hefte, the distinguished Catholic writer Dr. Eugen Kogon, author of the well-known book Der SS-Staat, published an article entitled "Kirchliche Kundgebungen von politischer Bedeutung."2 This article deals with an appeal of the Bavarian bishops and with a letter issued by the leaders of the Protestant church [and] has caused lively, one can even say, violent discussions in Catholic circles. Dr. Kogon's article contains two basic ideas:

1. The German church leaders should have defended their stand during the Third Reich with more courage and determination. Having failed to do that they can now advance their protest against the present violations of human right only in a restrained and conciliatory form.

2. Because of their past failure, it is not the German church dignitaries who are called to speak as the advocates of humanity but rather the church leaders of other countries who have had the courage of firmly opposing the spirit of violence even during the Hitler regime.

The conference of the German bishops held in Fulda from 19 to 21 August gave the undersigned the opportunity of interviewing the prominent church leaders as to their attitude on Kogon's article. The following personalities were interviewed by the undersigned: His Eminence Cardinal Josef Frings [18871978] of Cologne; Their Excellencies Bishop Albert Stohr [1890-1961] of Mainz,

1 The document has been slightly edited for clarity.

2 Kogon's book was translated into English as The Theory and Practice of Hell (New York: Farrar, Straus and Giroux, 1950).

(C) BERNAUER, 2018 | DOI 10.1163/22141332-00502007

This is an open access article distributed under the terms of the prevailing CC-BY-NC license at the time of publication. 
Archbishop Jaeger [1892-1975] of Paderborn, and Bishop Johannes Dietz [1879-1959] of Fulda.

Each of these church dignitaries had read Kogon's article and was well informed about the strong response with which his arguments had met in Christian circles. Kogon's assertation that the German church leaders had not fought Hitler with sufficient firmness was vehemently rejected by all interviewed dignitaries. The cardinal of Cologne stressed that Neuhäusler's book Kreuz und Hakenkreuz sufficiently proved that the German bishops had carried on a determined struggle against National Socialism. ${ }^{3}$ It was impossible during the Nazi regime, the cardinal said, to make this struggle publicly known, for in view of the brutality and ruthlessness of the adversary it was always a risky game with freedom and life. The least intensification of this fight would have been welcomed by the adversary as an opportunity to liquidate the mortally hated church leaders on the charge of high treason. "Who has the right," the cardinal said, "to demand that the bishops should have chosen a form of fight, which could have sent them to the gallows with infallible certainty, and which would have resulted in a campaign of extermination against the church? Such a fight would hardly have mitigated the inhumanities of the Hitler regime. It is probable that, on the contrary, it would have intensified them and that the Nazis would have dropped all disguise and prudence towards the church." "It is easy," said the archbishop of Paderborn, "to demand of another that he challenge certain death with a stake the success of which is more than dubious. It is highly probable that we would thus have attained just the opposite of our goal."

The bishop of Mainz stated: "Too often former concentration camp inmates wrongfully refer to their own experiences with the purpose of setting themselves as examples of the past. Actually, they were no more courageous than the bishops who are so lightly criticized today. Not many concentration camp inmates have knowingly challenged their fate by a public protest or by a public action, which infallibly meant the mental and physical anguish of the concentration camp. Only few of them have faced such an alternative and readily chose death. Most of them were thrown in concentration camps against their will as a result of indirect utterances and secret actions. Also, many of them became victims of their own imprudence and rashness, which have nothing to do with courage. I am far from counting Dr. Kogon among the latter. I know him personally very well and value him highly as a courageous and true Catholic. But I have the impression that this article is the expression of a

3 Johann Neuhäusler's book Kreuz und Hakenkreuz was published in 1946 by the Catholic Church of Munich. 
concentration camp psychosis, which has not remained without influence even on such a sharp and analytic mind as Dr. Kogon's."

Bishop Dietz of Fulda said to Kogon's accusation that the church had not fought Hitler with sufficient determination: "Kogon says: 'If you would have been more outspoken and firm in your protest against National Socialism you would also have the moral right of protesting today. But you have failed to do that." "This," bishop Dietz continued, "is an attack against which the bishops must no longer defend themselves as not only the pope but also the German bishops have published important documents that clearly prove their fight against Hitler. The historian who is aware of his responsibility will have to gather and carefully study all documentary evidence on our fight during the Third Reich. He will then arrive at a more moderate judgment. Much of this evidence is yet lacking, thus, for instance, the courageous fight of the bishops in sermons, on tours of confirmation, and other religious manifestations within their diocese. What is yet [to] become known is also a description of the extensive activity of the entire clergy. With their homiletic and catechetic activity our clergymen have endeavored to prevent an infiltration of National Socialist ideologies into the Catholic population. Therefore, it is wrong to assume that those who escaped imprisonment have failed to do their duty."

Cardinal Frings remarked at this point: "Of the soldiers fighting on a battlefield not only those are looked upon as heroes who are wounded but also those who come through the shower of bullets unharmed and can carry on the fight." Archbishop Jaeger of Paderborn said: "What would have happened if, through an imprudent fight of the bishops, the people would have been deprived of its priests? It is unfair towards the German church leaders, who were directly endangered, to play them off against other authorities who from a safe port could easily raise their voices in a more indignant and ardent protest. Even the church leaders of the occupied countries had the advantage of knowing that their actions would be backed by the entire people. But the German bishops had to be more careful as the political split had affected the entire German people. And besides, many members of our church, who had been blinded and misled by a deceitful propaganda would all the more have been driven into the arms of National Socialism by too sharp a language."

"Also, Dr. Kogon overlooks the fact that through its innermost nature the church has never been - and never will be-in a position of responding to violence with the same brutal methods," said the bishop of Fulda. "The basically pastoral attitude of the church is taken from the higher example set by Jesus when he was brought before the High Priests, before King Herod, and Pilate."

The cardinal said: "Kogon lacks the knowledge and the understanding of the decisions reached by the church in cases where the maius malum [greater evil] 
cannot be averted completely. In order not to overburden the faithful we had to choose the minus malum [lesser evil]."

All church dignitaries were unanimous in their opinion that Dr. Kogon had arrived at a wrong conclusion when he stated that the Germans had only a limited right to raise their voice in protest of present injustices. "It cannot be stressed often enough," said the bishop of Mainz, "that the 'German atrocities' have not been committed by the German people but by a numerically small group. As far as the German people knew of these atrocities it sharply rejected them at heart. But an outward or public protest could not take place as those protesting knew from the beginning that they would forfeit their life. Therefore, one cannot expect the German people as a whole to have acted like deathdefying heroes of whom there are only very few within any people."

The archbishop of Paderborn: "Kogon must be aware of the fact that, together with the interests of the church, the bishops have defended also the human rights. The sacredness of life, the sacredness of marriage, the dignity of man, the right of property, and personal esteem have been defended at the same time; all bishops have explicitly condemned murder. You will find this confirmed in the Witness and Struggle of the German Episcopacy, paragraph 5: 'The Situation of the Catholic Church in Germany: Memorandum of Cardinal Bertram (1859-1945) of Breslau to the Reich Government from Dezember 10, 1941'; also in the Pastoral Letter of the German Bishops from August 1943: The Ten Commandments as Laws of Life for the People [The pamphlet was published in 1946 by the Verlag Herder, Freiburg.]"

Cardinal Frings: "The bishop[s] will gladly follow Kogon's advice to consult advisory laymen. The nature and extent of their cooperation, however, and the selection of these laymen will be up to the bishops. The immeasurable distress and sorrow of our people assail us by day and by night. If the bishops were less restrained than they actually are they would have raised their voices long ago and probably not only on principle but also in connection with temporary events. The authority of our office and the dignity of our mission have guarded us from permitting ourselves to be carried away by the demanding mass of the believers, a mass which would like to see us engage the authority of our episcopal function in the saving of Germany from its present catastrophe."

The bishop of Mainz: "One of the most flagrant violations of the law committed by National Socialism was the proclamation of collective guilt of the Jews. Only because of its race the Jewish people was exterminated down to the youngest child. This ideology, which seemed to have been buried with the defeat of National Socialism, is now dangerously revived through the thesis of the collective guilt of the German people. Without distinction each German is declared guilty and responsible only because he is a German." 
All interviewed church leaders protested Kogon's assertion that the church is too lenient in its judgement of National Socialist crimes on the one side, and too harsh and severe in judging the inhumanities committed by other peoples on the other.

The archbishop of Paderborn: "It was clear to any intelligent observer during the Third Reich that the church condemned the Hitler Regime. And after the defeat the bishops have more than sufficiently, and with any desirable distinctness, uttered this condemnation from the pulpits. It would be time to abandon the quarrel over a liquidated system if there would not be the danger that the system revives in a new and modified form. Those who have so frankly admitted and deplored the guilt of their own fellow countrymen have doubtless also the right to resolutely fend off the injustice that is done to their own people. The nature of this defense will always be dictated by the extent and acuteness of the danger. It is useless to fight past injustices. But the present injustices can perhaps be mitigated with criticism. The injustices that happen today affect innumerable innocent Germans as brutally and as undeservedly as the despotism of the Hitler regime affected other people. There is the danger that the German people, which had almost been cured of National Socialism, will be forced back into this ideology by the injustice to which it is subjected today. Those who are hushing up the atrocities committed against innocent people in eastern and south-eastern Europe for reasons of political expediency render themselves guilty of the same offence as those who remained silent in the face of the atrocities committed by National Socialism. Just because we know that the Western powers are increasingly unwilling to tolerate the injustices committed in eastern and south-eastern Europe, our ardent protest is not an attack against these powers but rather a strengthening of their position."

The cardinal: "However great the revolting injustice of the Hitler regime has been when it ordered the forced evacuation of peoples: wrong will never become right, even if the same is done by the victors."

Bishop Dietz stressed that the people's faith in the church would suffer if the bishops remained silent. "When the disappointment and the bitterness of the millions will be deprived of an outlet the hopelessness of the people will grow beyond the bearable limit. Nobody can deny that the protest against a perpetuation of the captivity of our prisoners of war is justified. More than two years have now passed since the cessation of hostilities. Captivity is neither a detention nor slave-work but a means of preventing these prisoners of war from becoming soldiers again in case of a revival of the hostilities. In view of Germany's present situation such apprehensions are absurd. Therefore, it is against all human right if fathers, husbands, and sons are retained for now more than two years after a war of six long years. During the Third Reich any 
protest was from the beginning doomed to fail because terror and arbitrariness were reigning. But where human rights are granted on principle it is our duty to demand that they are respected."

The cardinal of Cologne concluded: "If the German episcopate remains silent in the face of the German people's terrible distress it will only smooth the path for radicalism and nihilism. In times of distress like the present it seems unwise to shake the faith of the people in its bishops and priests. But an article like Dr. Kogon's is too great a burden for the cooperation between priests and laymen. It is the most urgent demand of the hour that church and state, priests and laymen, assist and help each other in order to guide the people and help it overcome the greatest catastrophe of its history." 